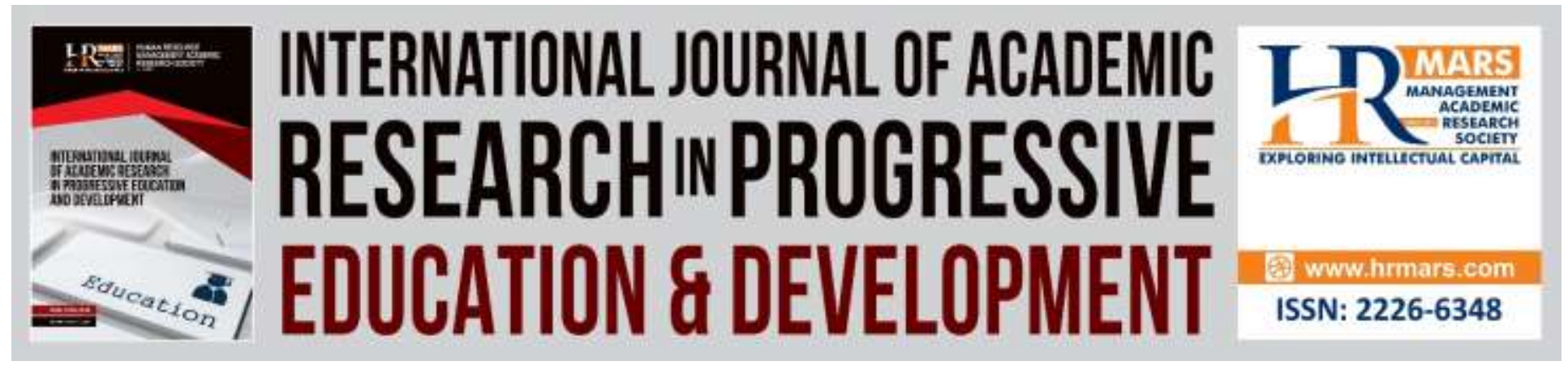

\title{
The Use of Social Media to Assist Writing Skills among Secondary Pupils
}

Che Surhaizai Che Wil, Melor Md. Yunus, Ashairi Suliman

To Link this Article: http://dx.doi.org/10.6007/IJARPED/v8-i3/6388

DOI: $10.6007 /$ IJARPED/v8-i3/6388

Received: 13 August 2019, Revised: 25 August 2019, Accepted: 06 September 2019

Published Online: 28 September, 2019

In-Text Citation: (Wil, Yunus, \& Suliman, 2019)

To Cite this Article: Wil, C. S. C., Yunus, M. M., \& Suliman, A. (2019). The Use of Social Media to Assist Writing Skills among Secondary Pupils. International Journal of Academic Research in Progressive Education and Development, 8(3), 224-236.

\section{Copyright: (C) 2019 The Author(s)}

Published by Human Resource Management Academic Research Society (www.hrmars.com)

This article is published under the Creative Commons Attribution (CC BY 4.0) license. Anyone may reproduce, distribute, translate and create derivative works of this article (for both commercial and non-commercial purposes), subject to full attribution to the original publication and authors. The full terms of this license may be seen

at: http://creativecommons.org/licences/by/4.0/legalcode

\section{Vol. 8(3) 2019, Pg. 224 - 236}

Full Terms \& Conditions of access and use can be found at http://hrmars.com/index.php/pages/detail/publication-ethics 


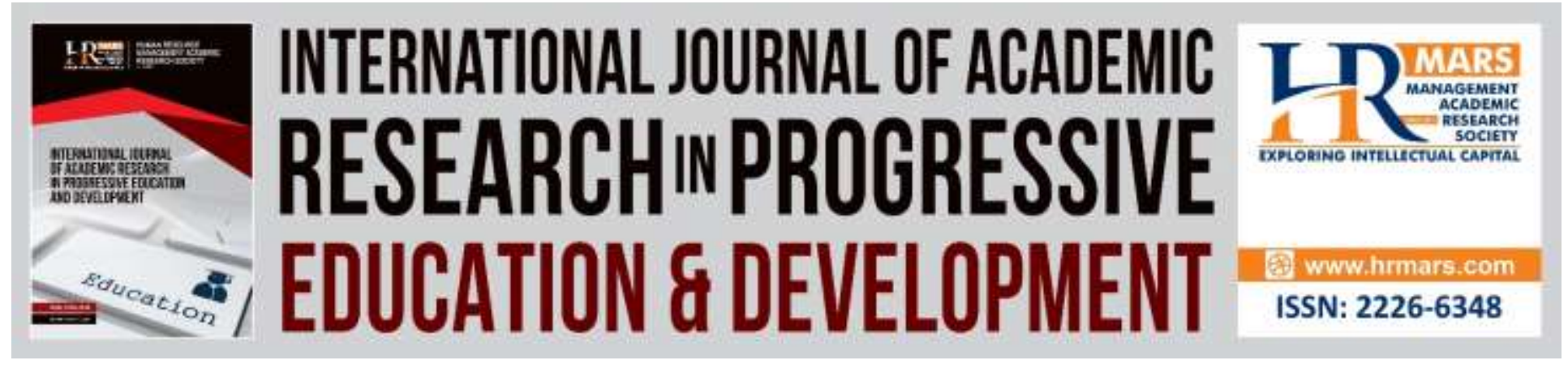

\title{
The Use of Social Media to Assist Writing Skills among Secondary Pupils
}

\author{
Che Surhaizai Che Wil ${ }^{1}$, Melor Md. Yunus ${ }^{2}$, Ashairi Suliman ${ }^{3}$ \\ ${ }^{1}$ Sekolah Menengah Kebangsaan Alor Pongsu, 34300 Bagan Serai, Perak \\ 2,3 Faculty of Education, Universiti Kebangsaan Malaysia, 43600 Bangi, Selangor, Malaysia \\ Email: chesurhaizaichewil@gmail.com
}

\begin{abstract}
Social media has become the most crucial online platform which functions to help connect people. People use social media for different purposes; meanwhile, pupils use social media widely in their daily routine and learning activities including writing. Hence, this study attempts to seek the use of social media to assist in writing skills among secondary school pupils. Data was collected via a questionnaire survey from 40 students in one secondary school. This study shows that respondents realized the benefit of using social media to assist writing but they did not spend much time on writing. The results of this study are hoped to identify whether social media can be one of the methods to assist in English writing skills.
\end{abstract}

Keywords: Social Media, Online Platform, Language Skill, Writing Skill

\section{Introduction}

Social media is a great place for pupils to express themselves because it encourages distinctiveness. The integration of gadgets and social media helps a lot. These technology enactments can be used for the allocation of information, communication platform and the vital use of educational reason (Hashim et al., 2018). It helps pupils to develop their confidence level by uploading status, voicing out opinions and writing in English on social media. Pupils are more into writing and show their interests when they write their essays out of the normality (Chandran et al., 2019). Writing rules on social media platforms are informal, thus it is undemanding for users who are not consummate in the English language to deliver their thoughts and ideas (Vikneswaran \& Krish, 2016). They also learn lots of new things instead of learning only vocabulary and grammatical rules, and online writing is a new method that needs to be implemented to enhance their English writing skills.

Amongst all skills in learning the English language, writing skills are the most strenuous skill to achieve by Malaysian pupils where teachers and pupils agreed that to accomplish the teaching and learning of writing is demanding (Chandran et al., 2019). Pupils in the new generation are having problems in writing formally. As Majid \& Stapa (2017) highlighted that even though pupils have been exposed and learned the language for 10 years and above in 
school, many pupils find it difficult to write a good essay in English. This is because learners have to conduct unrequited communication with the text with unfamiliar audiences and need to guess the feedbacks of the readers (Majid \& Stapa, 2017). However, they can get to the bottom of this problem by using social media as a platform for them to practice their writing correctly.

Most pupils in the school are identified as the competent users of social media especially Facebook, Instagram and WhatsApp. However, based on the survey that was conducted shows that they engaged with social media items mostly for fun rather than for academic purpose. As what is being highlighted by Chepkemoi, Situma \& Murunga (2018), Facebook and other social media items became popular through the development of knowledge in the usage information technology among teenagers, especially secondary pupils. Thus, the use of Facebook and other social media items apart from educational usage are identified as a factor that helps to damage their academic performance. Hence, the need to conduct this study is to investigate whether social media can assist in writing skills among pupils as one of the methods for them to learn how to write well in English. It is also to measure to what extent social media helps pupils to write better in the respective language.

\section{Research Gap}

Social media are not being used as top-notch in its role as a medium to assist pupils' learning, especially in writing activities. Not many researchers have taken interest in digging the negative effects of social media towards pupils' achievement and development in language learning, especially writing skills. Most of the researches are focusing only on the bright part of its role. A study by Chepkemoi, Situma \& Murunga (2018) emphasised that social media acts as the base of pleasure, where it performs the duty to clog and inhibit pupils' academic contrivance. This study highlights that the demands of writing competence are the basis of learning efforts to look for alternatives in improving writing skills.

Sulisworo, Rahayu \& Akhasan (2016) highlighted in their research that Facebook users are mainly school pupils where it is seen that the subject matter of their writings is very low. It regards that Facebook has not been superlatively used as a medium to assist learning activities among pupils. Current requirements associated with the aptness of communicative writing have become the groundwork for changes in the classroom's learning sodality. This research suggested that the need for in-depth monitoring from teachers to ensure that the pupils do not continue making errors in writing. However, a major problem became an obstruction where there is no specific allocation for learning to write by using social media in the classroom.

\section{Literature Review}

\section{Connectivism: Learning Theory for the Digital Age}

Learning theories describe how pupils absorb, process, and retain knowledge during the learning process. A real compete for any learning theory is to stimulate known knowledge at the point of execution (Siemens, 2005). The integration of social media in assisting writing skills was based on Connectivism learning theory where knowledge can be stored digitally and assigned across the information network (Kop \& Hills, 2008). This is where social media took place in helping respondents to gain and share information on the network communities such as Facebook, Instagram, WhatsApp, and other applications. 
Siemens (2005) stated that the introduction of new gadgets and informational tools within the latest digital technologies affect the improvement in pupils' abilities to explore new functions and usage in social media. Gamon \& McGranahan (2005) highlighted that to engage with students in the learning context via social media, instructors need to engage with educational activities as one of the important elements. This statement is supported by (Kop \& Hills, 2008) studies where they highlighted that learners may cross networks via multiple knowledge domains while Siemens (2005) stated that Connectivism learning theory is a theory needed to thrive in this digital era by highlighting the learning skills and tasks for learners.

\section{Writing Issue on ESL Learners}

Writing is an important skill in language production. Unfortunately, it is considered as the most difficult skill to be developed by learner especially secondary school pupils. Writing is the hardest skill to learn since it requires major usage of lexical and syntactic knowledge better than listening, speaking and reading skills (Tangpermpoon, 2008). Writing needs to be aligned with the ability to master grammatical rules and vocabulary. It shows that pupils who have a major knowledge of grammar and wider vocabulary content can write better than pupils with the lacking ability of both.

Incompetence in syntax, coherence, idea expansion, content selection, topic sentence, rhetorical conventions, mechanics, organization, lack and inappropriate use of vocabulary are general issues that occur in writing (Muhammad, Almas \& Muhammad, 2016). Therefore, they highlighted the issue that the development of this skill draws considerable attention for its learning and teaching from the very early phase of language education. Pupils need to develop their cognitive and analytical skills to improve their writing. Hyland (2002) stated that to express ideas in writing, pupils must master the writing skill effectively. Therefore, teachers should help pupils to learn writing skills that will help them write effectively and express themselves appropriately (Nyasimi, 2009).

\section{Integration of Social Media in Writing}

English learning has become more important in today's world. However, not many pupils are having the interest to learn English from academic resources such as attending classes and enroll themselves in tuition centres. Since writing is the most difficult skill that needs to be acquired, many pupils are meeting up with this latter. The integration of social media is the latest medium that is used as an innovative way to delegate education purposes. Social media is an interactive platform where users are able to generate contents based on mobile and web technologies for multiple sharing activities. Social media has a crucial impact where it is strictly based on webbased and it is a free, supportive and interactive enhancer for developing pupils' learning experiences in providing networking opportunities (Roopchund, Ramesh \& Janky, 2018). Pupils are more prone to autonomous learning techniques, monitoring such as reviewing and revising their writing process where it allows them to practice good writing including adjusting alternative sentence structures and removal of the improper articles (Laire, Casteleyn \& Mottart, 2012). Social media posts exposed pupils with the practice in editing to a limited word count, which means that pupils need to cut down any messages just to make it fit well. Zheng, Yim \& Warshauser (2018) stated that social media provides wider chances for second language learners 
to occupy daily writing activities and further improve pupils writing progress in classroom environment. These researchers also highlighted that social media as a medium of writing can impart the possibility for language learners to develop a conversation with native English speakers in veritable and persuading schemes while practising their written language.

\section{Methodology}

This part mainly deals with the methodology used in this study, which consists of four sections namely the research design, sampling, research instrument, and data collection procedures.

\section{Research Design}

The research is planning to use quantitative research method as the basis of the research to identify whether the respondents utilize social media as a tool to assist their writing skill in English.

\section{Sampling}

The study was conducted in a rural school in Bagan Serai, Malaysia. The respondents for this research were 40 secondary pupils from the intermediate level of proficiency.

\section{Research Instrument}

The research instrument used was a set of questionnaire, which consists of 6 sections. The questionnaire included a combination of both structured and open-ended questions. The respondents were asked to rank and stated yes or no and respond to the measurement of answers by using Likert-scales. Likert-scales were used to rationalize the pupils' level of authorization for each set of a statement. Sections 1-5 were constructed with 4 points scales meanwhile Section 6 was constructed with 5 points scale.

\section{Data Collection Procedures}

The process of gathering information was initiated by choosing 40 secondary pupils from the intermediate level of proficiency. They were asked to complete the questionnaires and provide their own opinions. The respondents were asked to rank and measure their answers on different questions with Yes or No and respond to the Likert-scale provided. Data were then collected, analysed using SPSS software and reported in tables using percentages. The finding shows that $40 \%$ of respondents agreed that the use of social media can assist their writing skills. 
INTERNATIONAL JOURNAL OF ACADEMIC RESEARCH IN PROGRESSIVE EDUCATION AND DEVELOPMENT

Vol. 8, No. 3, 2019, E-ISSN: 2226-6348 @ 2019 HRMARS

\section{Findings and Discussion}

The demographic data for this research is shown in the table below:

Table 1: Demographic Profile of Respondents

\begin{tabular}{llc}
\hline Gender & Male & $62.5 \%$ \\
& Female & $37.5 \%$ \\
Secondary & Four & $100 \%$ \\
& & \\
Duration of Use & & $22.5 \%$ \\
& $5-10$ hours & $32.5 \%$ \\
& $11-15$ hours & $45 \%$ \\
\hline
\end{tabular}

As Table I shows, the number of respondents is similar for both genders. $50 \%$ of respondents were male and another $50 \%$ were female. The data were collected from 40 Form four pupils. From the questionnaire, it shows that $22.5 \%$ of respondents logged in to social media for 5-10 hours, $32.5 \%$ of respondents logged in for $11-15$ hours and $45 \%$ of respondents logged in for 16 20 hours. The data shows that almost half of the respondents were engaged with the extreme usage of social media in their daily routine, to suit with the development of today's world.

Table 2: Access to ICT Tools

\begin{tabular}{clcc}
\hline & ACCESS & YES & NO \\
\hline $\mathbf{1}$ & Computer & $47.5 \%$ & $52.5 \%$ \\
\hline $\mathbf{2}$ & Laptop & $97.5 \%$ & $2.5 \%$ \\
\hline $\mathbf{3}$ & iPad & $30 \%$ & $70 \%$ \\
\hline $\mathbf{4}$ & Internet & $100 \%$ & $0 \%$ \\
\hline $\mathbf{5}$ & Using Social Media & $97.5 \%$ & $2.5 \%$ \\
\hline
\end{tabular}

As Table 2 shows, the accessibility towards the information and communication technology (ICT) depends on the tools that they have been exposed to. This is related to what parents' exposure towards ICT instruments and whether their children can use these at home (Heerwegh, De Wit \& Verhoeven, 2016). Among all these, all respondents have access to the Internet. This followed by $97.5 \%$ of accessing social media. The reason is that they can access those using smartphones and easy mobile data subscription. As most of the applications are easy to install and a very userfriendly, most of the respondents are having major accessibility towards the Internet and social media. $97.5 \%$ of respondents have access to a laptop while $2.5 \%$ did not. Most of them agreed that they only used the laptops during learning sessions in school with the guides of teachers and peers. The lowest can be seen where only $30 \%$ of respondents have access to iPad and $70 \%$ did not. Since iPads are quite costly and some of them could not afford to have one, they switched to a better option, smartphones. This is because most respondents have major access to smartphones rather than other tools. Families with high socioeconomic status and education are more equivalent to access and use these instruments without freely (Heerwegh, De Wit \& 
INTERNATIONAL JOURNAL OF ACADEMIC RESEARCH IN PROGRESSIVE EDUCATION AND DEVELOPMENT

Vol. 8, No. 3, 2019, E-ISSN: 2226-6348 @ 2019 HRMARS

Verhoeven, 2016).

Table 3: Social Media Usage

\begin{tabular}{cccccc}
\hline & SOCIAL MEDIA & NEVER & SELDOM & SOMETIMES & ALWAYS \\
\hline $\mathbf{1}$ & Facebook & $30 \%$ & $35 \%$ & $25 \%$ & $10 \%$ \\
\hline $\mathbf{2}$ & Twitter & $85 \%$ & $95 \%$ & $97.5 \%$ & $10 \%$ \\
\hline $\mathbf{3}$ & Wechat & $90 \%$ & $10 \%$ & $0 \%$ & $0 \%$ \\
\hline $\mathbf{4}$ & LINE & $90 \%$ & $5 \%$ & $5 \%$ & $0 \%$ \\
\hline $\mathbf{5}$ & Instagram & $7.5 \%$ & $17.5 \%$ & $12.5 \%$ & $62.5 \%$ \\
\hline $\mathbf{6}$ & YouTube & $10 \%$ & $35 \%$ & $55 \%$ & $0 \%$ \\
\hline $\mathbf{7}$ & Whatsapp & $2.5 \%$ & $5 \%$ & $27.5 \%$ & $55 \%$ \\
\hline $\mathbf{8}$ & Telegram & $65 \%$ & $25 \%$ & $10 \%$ & $0 \%$ \\
\hline $\mathbf{9}$ & Tik Tok & $82.5 \%$ & $10 \%$ & $5 \%$ & $2.5 \%$ \\
\hline $\mathbf{1 0}$ & Snapchat & $92.5 \%$ & $7.5 \%$ & $0 \%$ & $0 \%$ \\
\hline
\end{tabular}

As Table 3 shows, the usage of social media has been varied among respondents. Respondents are more familiar and interested in social media since it is a current medium of social interaction (Hashim et al., 2018). Since most of them own smartphones, they can access social media easily. The study aims to instruct media of how the human mind functions (Sorden, 2005). Among all of the social media, respondents tend to spend more time on Instagram. $62.5 \%$ of respondents always prefer to hook up with Instagram for reasonable purposes. This is because they can share photos and videos easily from smartphones. Those respondents who involved with online businesses have larger access in promoting their products via Instagram rather than other media.

WhatsApp application stated $55 \%$ usage among respondents. This is because it has becomes majorly used in communication since it is easy to access and came up with a very low price data connection, hence, it is a user-friendly application. Respondents tend to engage with this application since it is free and depends only on Internet coverage. The least usage is on Snapchat, where $92.5 \%$ of respondents never used this application and only $7.5 \%$ of respondents seldom used it. These were followed by WeChat and LINE where $90 \%$ of respondents never used both applications. This result might be affected by the lack of interest and constraint they have to apply to install these applications. 
INTERNATIONAL JOURNAL OF ACADEMIC RESEARCH IN PROGRESSIVE EDUCATION AND DEVELOPMENT

Vol. 8, No. 3, 2019, E-ISSN: 2226-6348 @ 2019 HRMARS

Table 4: Social Media Competency

\begin{tabular}{cccccc}
\hline & SOCIAL MEDIA & NOT APPLICABLE & WEAK & MODERATE & GOOD \\
\hline $\mathbf{1}$ & Facebook & $25 \%$ & $32.5 \%$ & $37.5 \%$ & $5 \%$ \\
\hline $\mathbf{2}$ & Twitter & $60 \%$ & $27.5 \%$ & $12.5 \%$ & $0 \%$ \\
\hline $\mathbf{3}$ & WeChat & $72.5 \%$ & $17.2 \%$ & $10 \%$ & $0 \%$ \\
\hline $\mathbf{4}$ & LINE & $80 \%$ & $10 \%$ & $5 \%$ & $5 \%$ \\
\hline $\mathbf{5}$ & Instagram & $12.5 \%$ & $15 \%$ & $37.5 \%$ & $35 \%$ \\
\hline $\mathbf{6}$ & YouTube & $5 \%$ & $22.5 \%$ & $42.5 \%$ & $30 \%$ \\
\hline $\mathbf{7}$ & WhatsApp & $2.5 \%$ & $17.5 \%$ & $25 \%$ & $55 \%$ \\
\hline $\mathbf{8}$ & Telegram & $62.5 \%$ & $25 \%$ & $10 \%$ & $2.5 \%$ \\
\hline $\mathbf{9}$ & Tik Tok & $72.5 \%$ & $15 \%$ & $7.5 \%$ & $5 \%$ \\
\hline $\mathbf{1 0}$ & Snapchat & $82.5 \%$ & $15 \%$ & $0 \%$ & $2.5 \%$ \\
\hline
\end{tabular}

As Table 4 shows, the competency of using social media is varied. Respondents' levels of competence are measure based on types of social media they are exposed to. Students can retrieve the required information within a short time by using the latest technology in information and communication (Danner \& Pesso, 2013; Matarid, Sobh, \& Ahmed. 2018). Among all these, respondents show the highest level of competency in using WhatsApp application. 55\% of respondents were good users and $25 \%$ of respondents knew how to use WhatsApp moderately. The reason is that it is a free application and can be accessed easily. Meanwhile, it became the most superior usage since it allows free connectivity and being used worldwide.

Instagram took second where $35 \%$ of respondents were good users while $37.5 \%$ used it moderately. However, about $2.5 \%$ of respondents did not have competencies in using Instagram, related to the reason that they did not have smartphones and easy access Internet connection. Snapchat provides the lowest competency since $82.5 \%$ are not applicable for the respondents and only $2.5 \%$ of respondents knew how to use it well. It followed by LINE application where $80 \%$ of respondents are not applicable and only 5\% knew how to use it moderately and another 5\% knew how to use it well. This finding exposed that respondents are more attempt to get engage with WhatsApp since it is more beneficial, easier and free; thus, they only need a stable Internet connection. 
Vol. 8, No. 3, 2019, E-ISSN: 2226-6348 @ 2019 HRMARS

Table 5: Reasons for Using Social Media

\begin{tabular}{|c|c|c|c|c|c|}
\hline ITEM & S.D & D & A & $\begin{array}{l}\text { S. } \\
\text { A }\end{array}$ & MEAN \\
\hline I use SM to & $5 \%$ & 2.5 & 35 & 57 & 3.45 \\
\hline communicate & & $\%$ & $\%$ & .5 & \\
\hline with my friends & & & & $\%$ & \\
\hline I use SM to & 2.5 & 7.5 & 35 & 55 & 3.43 \\
\hline $\begin{array}{l}\text { communicate } \\
\text { with my family }\end{array}$ & $\%$ & $\%$ & $\%$ & $\%$ & \\
\hline I use SM to learn & 7.5 & $20 \%$ & 55 & 17 & 2.83 \\
\hline new things & $\%$ & & $\%$ & .5 & \\
\hline & & & & $\%$ & \\
\hline I use SM to follow & 7.5 & 17.5 & 57 & 17 & 2.85 \\
\hline my favorite & $\%$ & $\%$ & .5 & .5 & \\
\hline artiste & & & $\%$ & $\%$ & \\
\hline I use SM to learn & 7.5 & 7.5 & 57 & 2. & 3.07 \\
\hline English & $\%$ & $\%$ & .5 & 5 & \\
\hline & & & $\%$ & $\%$ & \\
\hline I use SM to fill my & 7.5 & $60 \%$ & 30 & 2. & 3.28 \\
\hline free time & $\%$ & & $\%$ & 5 & \\
\hline & & & & $\%$ & \\
\hline I use SM to gain & $0 \%$ & $20 \%$ & 42 & 37 & 3.18 \\
\hline knowledge & & & .5 & .5 & \\
\hline & & & $\%$ & $\%$ & \\
\hline I use SM to follow & $0 \%$ & $25 \%$ & 57 & 25 & 3.08 \\
\hline the current trend & & & .5 & $\%$ & \\
\hline $\begin{array}{l}\text { (fashion, movie, } \\
\text { music) }\end{array}$ & & & $\%$ & & \\
\hline I use SM because & $0 \%$ & $5 \%$ & 50 & 45 & 2.88 \\
\hline my friends use it & & & $\%$ & $\%$ & \\
\hline I use SM to do & $0 \%$ & 2.5 & 52 & 45 & 2.00 \\
\hline business & & $\%$ & .5 & $\%$ & \\
\hline & & & $\%$ & & \\
\hline I use SM because & 2.5 & 2.75 & 50 & 20 & 3.40 \\
\hline it is easy to use & $\%$ & $\%$ & $\%$ & $\%$ & \\
\hline I use SM because & $35 \%$ & $35 \%$ & 25 & 5 & 3.42 \\
\hline it is useful to me & & & $\%$ & $\%$ & \\
\hline
\end{tabular}

As Table 5 shows several reasons made respondents choose to use social media. $92.5 \%$ of respondents were on the positive agreement that they use social media to communicate with their friends, where only $5 \%$ disagreed that they use social media for this purpose. The second reason is they use social media to communicate with their family. It shows that $55 \%$ of respondents agreed with this statement. Among all those reasons, 57.5\% agreed that they use social media to follow their favorite artists, $57.5 \%$ agreed that they use social media to follow the current trend and $57.5 \%$ agreed that they use social media to learn English. However, 35\% of respondents strongly disagreed that they use social media because it is useful to them and $60 \%$ disagreed that they use social media to fill their free time. According to these findings, it shows that the major reason for them to use social media is for communicating with their friends and family. Regarding today's technologies where everything is just on the fingertips, not many 


\section{INTERNATIONAL JOURNAL OF ACADEMIC RESEARCH IN PROGRESSIVE EDUCATION AND}

DEVELOPMENT

Vol. 8, No. 3, 2019, E-ISSN: 2226-6348 @ 2019 HRMARS

people are aware of the usage of the traditional method to communicate. Roopchund, Ramesh and Janky (2018) stated that people use social media as a compulsory daily routine and apparently, the scope for using it in the field of education is higher.

Table 6: Social Media Roles to Assist Writing Skill

\begin{tabular}{|c|c|c|c|c|c|c|}
\hline & ITEM & S.D & D & $\mathrm{N}$ & A & S.A \\
\hline 1 & $\begin{array}{l}\text { I write my status in Social } \\
\text { Media using the English } \\
\text { language }\end{array}$ & $5 \%$ & $15 \%$ & $35 \%$ & $32.5 \%$ & $12.5 \%$ \\
\hline 2 & $\begin{array}{l}\text { I reply to people's } \\
\text { comments in SM using } \\
\text { the English language }\end{array}$ & $15 \%$ & $20 \%$ & $35 \%$ & $27.5 \%$ & $2.5 \%$ \\
\hline 3 & $\begin{array}{l}\text { I learn new vocabularies } \\
\text { of English language by } \\
\text { using SM }\end{array}$ & $12.5 \%$ & $2.5 \%$ & $17.5 \%$ & $52.5 \%$ & $15 \%$ \\
\hline 4 & $\begin{array}{l}\text { SM helps me writes } \\
\text { better in English }\end{array}$ & $7.5 \%$ & $5 \%$ & $12.5 \%$ & $52.5 \%$ & $22.5 \%$ \\
\hline 5 & $\begin{array}{l}\text { SM helps me to increase } \\
\text { my confidence level to } \\
\text { write in English }\end{array}$ & $7.5 \%$ & $5 \%$ & $27.5 \%$ & $47.5 \%$ & $12.5 \%$ \\
\hline 6 & $\begin{array}{l}\text { SM helps me to increase } \\
\text { my } \\
\text { frequency of } \\
\text { participation in } \\
\text { English writing } \\
\text { activities. }\end{array}$ & $7.5 \%$ & $2.5 \%$ & $22.5 \%$ & $55 \%$ & $12.5 \%$ \\
\hline 7 & $\begin{array}{l}\text { I believe that SM is the } \\
\text { best platform to write } \\
\text { better English }\end{array}$ & $7.5 \%$ & $5 \%$ & $22.5 \%$ & $52.5 \%$ & $12.5 \%$ \\
\hline 8 & $\begin{array}{l}\text { Social media } \\
\text { provides advantages to } \\
\text { my writing skill }\end{array}$ & $7.5 \%$ & $20 \%$ & $40 \%$ & $37.5 \%$ & $0 \%$ \\
\hline 9 & $\begin{array}{ll}\text { Social media } & \text { provides } \\
\text { disadvantages } & \text { to my } \\
\text { writing skill } & \end{array}$ & $7.5 \%$ & $27.5 \%$ & $52.5 \%$ & $12.5 \%$ & $0 \%$ \\
\hline 10 & $\begin{array}{l}\text { Social media can assist } \\
\text { my English language } \\
\text { writing skill in my daily } \\
\text { life }\end{array}$ & $0 \%$ & $12.5 \%$ & $37.5 \%$ & $40 \%$ & $10 \%$ \\
\hline
\end{tabular}

As Table 6 shows, social media plays many roles in assisting respondents to write with better skill. Students will experience language authentically via social networking platform (Yunus et al., 2016). Through the findings, $75 \%$ were on the positive agreement that social media helps them to write better in English. 55\% of respondents agreed that social media helps them to increase their frequency of participation in English writing activities, followed by $52.5 \%$ agreed that social 
media is the best platform to write better English. $52.5 \%$ were neutral about social media provides disadvantages to their writing skill meanwhile $0 \%$ strongly agreed and $40 \%$ were neutral that social media provides advantages to their writing skill meanwhile $0 \%$ strongly agreed on this statement.

Based on the findings, it shows that social media do assist respondents to write better in English. This result indicated a significant impact of the usage of social media which suggest its effectiveness in aiding pupils to comprehend and to better contextualize the content of their writing. Pupils were able to write comprehensively after the introduction of social media's platform. Moreover, social media assists respondents to write better by interacting through visual communication, improve their communication skills by learning new languages and read online sample essays (Hashim et al., 2018). This is because social media is not only interesting for learning but it is also loaded with important information, as a fun and interactive medium.

\section{Conclusion and Implication}

Social media portrayed as bad influence for teenagers. Despite the fact of rumour, social media does have its advantages as shown in the findings. The use of social media as an aim to assist pupils in writing skill has shown both positive and negative aspects. The results revealed pupils' positive acceptances and responses towards using social media in improving their skills in writing. The uses of multiple learning strategies that encourage pupils to become more active be inclined to improve the capability for them to explore for new creativity. It has arrived at the main aim of this study, is to present the needs of using social media as a tool to assist pupils' writing skills. It is found that social media can bring positive effects to promote enjoyment and facilitates the writing process where most of them use social media to learn English language, and believed that social media is the best platform to develop better writing skills in English. Yunus et al. (2016) agreed that social networking such as social media is better than the traditional way of helping pupils to write better in English. This was supported by Altunkaya \& Topuskananiz (2018), where they mentioned that even though it could be altercated that when compared the practice of Facebook to the traditional way, it has provided positive outcome on writing achievement and writing attitude, at the same time approved that a single factor was not practical in increasing the accomplishment.

This study hopes that social media is a convenient tools to help pupils learn better and prepare them for the needs of Industrial Revolution (IR) 4.0. As we are moving into the glory days of digital world, social media provides chances for pupils to become a technophile. The used of Internet, computer, and technology are most encourage since it can expose pupils to the industrial principle of Internet of Things (IOT) through social media. Shahroom \& Hussin (2018); Sangakala, Ahmed, \& Pahi (2016) stated that $21^{\text {st }}$ learning century have turned the motion of education and comprehensive cultivate aspect into computerized teaching process and smart classroom. The researchers also highlighted that teachers should explore new and creative strategy to employ educational innovation for future learning. As for this matter, social media is recommended as an effective medium that can be used by teachers for developing writing skills as a start. The study recommends the role of teachers by conducting online classes and group discussions through social media so that they can observe, guide and assist pupils in formal writing. Therefore, this study shows that incorporating social media as a tool in writing activity 
INTERNATIONAL JOURNAL OF ACADEMIC RESEARCH IN PROGRESSIVE EDUCATION AND DEVELOPMENT

Vol. 8, No. 3, 2019, E-ISSN: 2226-6348 @ 2019 HRMARS

can assist in better writing skills among pupils. It is also hope to help teachers to create a fulfilling lesson.

\section{Corresponding Author}

Che Surhaizai binti Che Wil, Melor binti Md Yunus, Ashairi bin Suliman, Faculty of Education, Universiti Kebangsaan Malaysia, Selangor, Malaysia Email: chesurhaizaichewil@gmail.com

\section{References}

Altunkaya, H. \& Topuzkananis, E. (2018). The Effect of Using Facebook in Writing Educational on Writing Achievement, Attitudes, Anxiety and Self-efficacy Perception. Universal Journal of Educational Research, Vol. 6(10): 2133-2142.

Chandran, Y., Plaindaren, C. J., Pavadai, S. \& Yunus, M. M. (2019). Collaborative Writing: An Integration of Snack Bars and Hi-Five Fingers via Social Media. Creative Education, Vol. 10, 475-484.

Chepkemoi, K. C., Situma, J., \& Murunga, F. (2018). Influence of Facebook Social- Media Usage on Students' Spellings in English Written Assignments in Public Day Secondary Schools in Eldoret North Sub-County. International Journal of Academic Research in Business and Social Sciences, Vol. 8(8), 159-171.

Danner, R. B. \& Pesso, C. O. A. (2013). A Survey of ICT Competencies among Students in Teacher Descriptive Writing among ESL Learners. The Southeast Asian Journal of English Language Studies, Vol. 23(4): 77-78.

Gamon, M. A. \& McGranahan, C. (2015). Theory Through Application: A Study in the Use of Social Media for Teaching. Journal of Faculty Development, Vol. 29, No. 2.

Hashim, H., Yunus, M. M., Ibrahim, N. S. M., Jeri I. E., Sukr, M. A. M., Ilahi, N. S. N. \& Hassim, M. A. N. (2018). Social Media and Its Impact on Students' Writing Skill. International Journal of Engineering \& Technology, Vol. 7(4.21) 102-106.

Heerwegh, D., Wit, D. K. \& Verhoeven, J. C. (2016). Exploring the Self-reported ICT Skill Levels of Hyland, K. (2002). Teaching and Researching Writing. Harlow: Longman.

Implementating Blended Learning Using Facebook. Information Technologies and Learning Tools, Vol 56, No. 6.

Instructional Technology and Distance Learning, Vol. 2(1), 3-10.

International Review of Research in Open and Distance Learning, Vol.9 No. 3.

Kop, R. \& Hill, A. (2008). Connectivism: Learning Theory of the Future or Vestige of the Past?

Laire, D., Casteleyn, J. \& Mottart, A. (2012). Social Media's Learning Outcomes within Writing Instruction in the EFL Classroom: Exploring, Implementing and Analyzing Storify. Procedia - Social and Behavioral Sciences, Vol. 69 (2012) 442 - 448.

Majid, A. H. A. \& Stapa, S. H. (2017). The Use of Scaffolding Technique via Facebook in Improving

Matarid, N. M., Sobh, O. S., \& Ahmed, U. (2018). The Impact of Organizational Justice and Demographics on Faculty Retention in Bahrain. Le travail humain, (3).

Muhammad, F., Almas, A. \& Muhammad, B. (2016). ESL Learners' Writing Skills, Problems, Factors, and Suggestions. Journal of Education and Social Science. Vol. 4(2): 1. 
Nyasimi, N. B. (2009). Challenges Students Face in Learning Essay Writing Skills in the English Language in Secondary School in Manga District, Nyamira County, Kenya. School of Education in Kenyatta University, Vol. 2.

Preparation Programmes at the University of Benin, Benin City, Nigeria. Journal of Information Technology Education, Vol. 12.

Roopchund, R., Ramesh, V. \& Janky, R. (2018). Use of Social Media for Improving Student Engagement at Université des Mascareignes (UDM): Proceedings of Fifth International Conference INDIA 2018, Vol. 2.

Sangakala, M., Ahmed, U., \& Pahi, M. H. (2016). Empirical investigating on the role of supervisor support, job clarity, employee training and performance appraisal in addressing job satisfaction of nurses. International Business Management, 10(23), 5481-5486.

Shahroom, A. A. \& Hussin, N. (2018). Industrial Revolution 4.0 and Education. International Journal of Academic Research in Business and Social Sciences, Vol. 8, No. 9.

Siemens, G. (2005). Connectivism: A Learning Theory for the Digital Age. International Journal of

Sorden, S. D. (2005). A Cognitive Approach to Instructional Design for Multimedia Learning Informing Science. International Journal of an Emerging Transdiscipline, Vol.8, 263-279.

Sulisworo, D., Rahayu, T. \& Akhsan, N. R. (2016). The Students' Academic Writing Skills After

Tangpermpoon, T. (2008). Intergraded Approaches to Improve Students' Writing Skills for English Major Students. ABAC Journal, Vol. 28, 1-9.

Undergraduate Science Students. Journal of Information Technology Education, Vol.14, 19-47.

Yunus, M. M., Salehi, H., Amini, M., Shojaee, M. \& Wong, Y. F. (2016). Activities and Suggestions for Using Social Networking in Teaching ESL Writing. Journal of Theoretical and Applied Information Technology, Vol. 84 No. 2.

Zheng, B., Yim, S. \& Warschauser, M. (2018). Social Media in the Writing Classroom and Beyond. The TESOL Encyclopedia of English Language Teaching, 1-5. 